\title{
Effects of obesity on upper extremity range of motion in children
}

\author{
Çocuklarda obezitenin üst ekstremite eklem hareket açıklı̆̆ üzerine etkisi
}

\author{
Fırat Erdoğan, ${ }^{1}$ Evrim Şenkal, ${ }^{2}$ Mustafa Çiftçi, ${ }^{2}$ Erkan Doğan, ${ }^{3}$ Mert Keskinbora, ${ }^{4}$ Mustafa Şahin, ${ }^{5}$ Ömer Ceran ${ }^{1}$ \\ ${ }^{1}$ Department of Pediatrics, İstanbul Medipol University, İstanbul, Turkey \\ ${ }^{2}$ Department of Pediatrics, İstanbul Medipol Hospital, İstanbul, Turkey \\ ${ }^{3}$ Department of Pediatrics, Medical Faculty of Karabük University, Karabük, Turkey \\ ${ }^{4}$ Department of Orthopaedics, Istanbul Medipol Hospital, İstanbul, Turkey \\ ${ }^{5}$ Department of Orthopaedics, İstanbul Medipol University, İstanbul, Turkey
}

\begin{abstract}
Objectives: This study aims to assess the effects of obesity on upper extremity range of motion in children.

Materials and methods: This cross-sectional study covers 153 participants ( 85 boys, 68 girls; mean age $8.3 \pm 3.6$ years; range 2 to 16 years) admitted in the pediatrics clinic of our hospital between January 2014 and December 2015. We evaluated the participants' body mass indexes (BMI) according to the percentile chart recommended by World Health Organization and they were divided into three groups as normal weight $(n=53)$, overweight $(n=50)$ and obese $(n=50)$. We measured the participants' upper extremity ranges of motion (ROM) - elbow extension and flexion angles, carrying angle and shoulder abduction angle - by using a standard 12-inch plastic goniometer.

Results: There was no statistically significant difference between the right and left joint angle measurements. No relationship was found between the age and flexion moment in each BMI groups. We found significant difference between BMI percentile and elbow extension and ROM levels, however there was no statistically significant difference between the gender and ROM measurements. No statistical difference was determined in terms of ROM in any joint in either between the groups of normal weight and overweight or between the overweight and obese groups. Although there was no significant difference at flexion angle measurements between normal weight and obese groups, we found statistically significant difference in extension angle measurements.

Conclusion: Obesity causing restricted movement in the upper extremities may lead children to a more sedentary lifestyle by reducing their will to participate in daily activities such as sports and games. Therefore children with decreased energy expenditure will have weight gain trends and their obesity problems will deepen.
\end{abstract}

Keywords: Children; joint; obesity; range of motion; upper extremity.

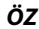

Amaç: Bu çalışmada çocuklarda obezitenin üst ekstremite eklem hareket açıklığı üzerine etkisi değerlendirildi.

Gereç ve yöntemler: Bu çapraz kesitli çalışmaya Ocak 2014 - Aralık 2015 tarihleri arasında hastanemizin çocuk kliniğine başvuran 153 katılımcı (85 erkek, 68 kız; ort. yaş $8.3 \pm 3.6$ yıl; dağılım 2-16 yıl) dahil edildi. Katılımcıların vücut kitle endeks (VKi)'leri Dünya Sağlık Örgütü'nün önerdiği persentil tablosuna göre değerlendirildi ve normal $(n=53)$, kilolu $(n=50)$ ve obez $(n=50)$ olmak üzere üç gruba ayrıldı. Katılımcıların üst ekstremite eklem hareket açıkıkları (EHA) - dirsek eklemi ekstansiyon ve fleksiyon açıarı, taşıma açısı ve omuz eklemi abdüksiyon açısı - standart plastik 12 gonyometre kullanılarak ölçüldü. Bulgular: Sağ ve sol eklemler açı ölçümleri arasında istatistiksel olarak anlamlı fark saptanmadı. Vücut kütle endeks grupları arasında, yaş ve fleksiyon momenti açısından herhangi bir ilişki bulunmadı. Dirsek ekstansiyon açısı ve EHA seviyeleri ile VKi persentili arasında anlamlı fark bulundu, ancak cinsiyet ve EHA ölçümleri arasında anlamlı fark bulunmadı. Ne normal ve kilolu gruplar ne de kilolu ve obez gruplar arasında hiçbir eklemde EHA açısından anlamlı fark saptanmadı. Normal kilolu ve obez gruplar arasında eklem fleksiyon açısı ölçümlerinde istatistiksel olarak anlamlı fark bulunmamasına karşın eklem ekstansiyon açısı ölçümünde anlamlı fark saptandı.

Sonuç: Obezite üst ekstremite hareketlerinin kısıtlanmasına neden olarak ve çocukların spor veya oyun gibi günlük aktivitelere katılma isteklerini azaltarak daha hareketsiz bir yaşam sürmelerine yol açabilir. Bu nedenle enerji harcaması azalan çocukların kilo alma eğilimleri olacak ve obezite sorunu derinleşecektir.

Anahtar sözcükler: Çocuklar; eklem; obezite; eklem hareket açıklı̆ı̆ üst ekstremite.

Received: March 11, 2016 Accepted: July 28, 2016

Correspondence: Fırat Erdoğan, MD. Özel İstanbul Medipol Hastanesi, Çocuk Hastalıkları Bölümü, 34718 Kadıköy, İstanbul, Turkey.

Tel: +90 533 - 6425480 e-mail: firaterdogan34@gmail.com 
Obesity is an important health problem in the pediatric population. Over the last 30 years, the prevalence of obesity has increased two-fold for children and four times for adolescents. ${ }^{[1,2]}$ Besides a sharp increase in the frequency of this global health problem, obesity becomes more of an issue due to the effects on many other systems of the body. According to reports from the World Health Organization (WHO) in 2013, there were more than 42 million overweight children younger than five in the world and 31 million of them were living in developed countries. Moreover, it is known that overweight children younger than five years old, have an increased risk for obesity in adulthood. ${ }^{[3,4]}$

The relationship between obesity and diabetes mellitus, cardiovascular problems, certain types of cancer (especially breast, colon, endometrium) has been shown in many studies. ${ }^{[3,5,6]}$ However, there are less serious effects in some cases, such as bone and joint problems, sleep apnea and psychological problems. ${ }^{[7-9]}$

As a result of the bone and joint problems caused by obesity, children hesitate to participate in sports, games and other activities. This can result in a decrease in energy consumption which can lead to a further increase in weight, which may worsen the effects of obesity. ${ }^{[7,9]}$

Previous studies have indicated that a sedentary lifestyle is not only a risk for obesity, but also an important risk factor for many other systemic diseases. Alterations in joint function may lead to severe degenerative joint problems that can be seen in early adulthood. In their study, Golden et al. ${ }^{[10]}$ reported the negative correlation between body mass index (BMI) and joint range of motion (ROM). In accordance with these findings, it is clear that regular physical activities improve weight control, prevent cardiovascular diseases and provide strength to the musculoskeletal system. ${ }^{[11]}$

Although, many studies focus on the systemic effects, medical and surgical treatment of obesity, there are a very limited number of studies evaluating the influence of obesity on joint motion in the pediatric population. The aim of this study is to observe and interpret the effects of obesity on joint motion in children.

\section{MATERIALS AND METHODS}

A cross-sectional study of 153 participants ( 85 boys, 68 girls; mean age $8.3 \pm 3.6$ years; range 2 to 16 years) was conducted in the pediatric clinic of Istanbul Medipol Hospital over a two year period, between January 2014 and December 2015. Individuals who had additional orthopedic deformities, history of previous fractures, neurological disorders that precludes walking or chronic systemic diseases were excluded. Demographic information was obtained from hospital records. The study protocol was approved by the Special Istanbul Medipol Hospital Ethics Committee. Institutional review board approval was obtained for the project, and consent was obtained from all participants before they participated in the study (09/09/2014-10840098222). The study was conducted in accordance with the principles of the Declaration of Helsinki.

The most frequently used measurement method for obesity, described as abnormal fat deposit in the body, is the BMI. Body mass index is calculated by dividing a person's weight in kilograms to his or her height squared in meters. Different classifications are used for evaluating the obtained BMI rate. The WHO recommends the following percentile table according to age and gender: $\mathrm{BMI}$ rate lower than $5 \%$ is slim, $5-85 \%$ is the normal range, $85-95 \%$ is overweight and 95\% and over is obese. ${ }^{[4]}$ Measurements were taken as follows:

Body mass; measured by the same nurse, using a digital 100 grams sensitive weighing scale with regular calibration. Only underwear was allowed during the survey.

Height; measured by the same nurse, using a "harpenden stadiometer" with the patient in upright standing position.

Body mass index; $\mathrm{BMI}=$ Body mass $(\mathrm{kg}) /$ square of body height $\left(\mathrm{m}^{2}\right)$.

Fifty-three patients (34.6\%) were classified into the "normal weight" group, 50 patients (32.7\%) were classified as "overweight" and 50 patients (32.7\%) were deemed as "obese". There was no significant difference between the ages of the male and female patients between the two groups. Baseline demographic data of all groups were similar with regard to age and gender $(p=0.255, p=0.652$, respectively). 


\section{Measuring range of motion}

Range of motion was evaluated by measuring elbow flexion and extension angles, carrying angle and shoulder abduction angle. A standard "plastic 12 goniometer" was used to measure joint motion angles.

In order to measure carrying angle, the elbow was fully extended and 0 degree flexed. The goniometer was placed on the volar surface of cubital fossa, and aligned according to arm and forearm median axis. ${ }^{[12]}$

Elbow flexion and extension and ROM were measured with the person either in a sitting or standing position with the shoulder adducted and flexed in neutral position and with the elbow, wrist, and interphalangeal joints extended. Elbow range of motion was assessed by aligning the goniometer on the lateral aspects of both arms to measure flexion and extension. The fulcrum of the goniometer was aligned anteroinferior to the lateral condyle, approximately in the center of the arcs formed by the trochlear sulcus and capitellum. The center of the arcs formed by the trochlear sulcus and capitellum was identified as the center of the axis of rotation for the elbow joint. The distal arm of the goniometer was aligned parallel to the long axis of the forearm. The proximal arm of the goniometer was aligned parallel to the shaft of the humerus. Then the patient was asked to actively flex and extend the arm through the full ROM. Flexion was measured with $0^{\circ}$ defined as the starting point (no flexion). Extension was measured similarly $\left(0^{\circ}\right.$ as the starting point), where as over extension angles (cubital recurvatum) were defined in minus degrees. Total ROM was then calculated by subtracting extension from flexion. ${ }^{[13]}$

Shoulder abduction was measured while the patient was in an upright standing position. The elbow and wrist was fully extended, with shoulder and arm slightly internally rotated while the forearm and hand were slightly pronated. The patient was asked to raise his/her upper-limb as high as he/she could, then the measurement was made in the axial plane. ${ }^{[12]}$

According to the classification recommended by $\mathrm{WHO}$; children below the percentile of $85 \%$ are in the first group and accepted as "normal weight"; in the second group, children between 85-95\% are accepted as "overweight"; and in the third group, children over the percentile of 95\% are accepted as "obese".

\section{Statistical analysis}

All data was analyzed using IBM SPSS version 20.0 software for Windows (IBM Corporation, Armonk, NY, USA). For demographic data analysis, definitive statistical methods (frequency, percent, mean, standard deviation) were calculated. For comparing variable subgroups, $\mathrm{t}$ test and mono variant analysis test was used. Results were evaluated at a safety interval of 95\% and "p" values $<0.05$ was accepted as statistically significant.

\section{RESULTS}

All patients were healthy, with regard to physical examination and outcome assessment.

There was no significant statistical difference between the right and left joint angle measurements (Table 1). We used the data gained from right upper extremities of every patient in order to compare the statistical analysis of joint angles between age and gender.

No relationship was seen between age and flexion moment in each BMI group ( $\mathrm{R} 2=0.04$, $\mathrm{p}=0.14 ; \mathrm{R} 2=0.004, \mathrm{p}=0.71 ; \mathrm{R} 2=0.023, \mathrm{p}=0.55$ for the normal weight, overweight and obese individuals, respectively). The relationship remained the same when gender analyzed in

Table 1. Comparing right and left angle measurements

\begin{tabular}{lcccc}
\hline & Right & & Left & \\
\cline { 2 - 2 } & Mean \pm SD & & Mean \pm SD & $p^{*}$ \\
\hline Elbow extension & $173.94 \pm 6.78$ & & $174.2157 \pm 7.08$ & 0.328 \\
Elbow flexion & $119.97 \pm 33.66$ & & $119.6471 \pm 34.22$ & 0.549 \\
Shoulder abduction & $166.59 \pm 12.14$ & & $166.67 \pm 10.82$ & 0.852 \\
Carrying angle & $11.14 \pm 5.53$ & & $10.22 \pm 5.20$ & 0.545 \\
Range of motion & $113.92 \pm 33.00$ & & $113.92 \pm 32.60$ & 0.991 \\
\hline SD: Standard deviation; * Paired sample t-test.
\end{tabular}


Table 2. Statistical analysis of right joint angle measurements to gender

\begin{tabular}{lc}
\hline & $p^{*}$ \\
\hline Elbow extension** & 0.658 \\
Elbow flexion*** & 0.445 \\
Shoulder abduction"** & 0.532 \\
Carrying angle** $^{* * *}$ & 0.112 \\
Range of motion** & 0.741 \\
\hline${ }^{*}$ Chi-square test; ${ }^{* *}$ Percentile. &
\end{tabular}

all study groups (flexion moment: R2 $=0.056$, $\mathrm{p}=0.203 ; \quad \mathrm{R} 2=0.03, \quad \mathrm{p}=0.31 ; \quad \mathrm{R} 2=0.024$, $p=0.221$; for the normal weight, overweight and obese individuals, respectively) (Table 2).

When gender and percentile characteristics were compared; there was a significant difference between BMI percentile and elbow extension and ROM levels $(p=0.039$ and $p=0.02$, respectively), while there was not a statistically significant difference between gender and angle measurements (Table 3).

In analysis of joint angles between groups, there was not a statistical difference between any angle of the groups of normal weight and overweight, the same was valid between the overweight and obese groups.

As for the statistical analysis between "normal weight" and "obese" groups, there is no significant difference at flexion (right elbow; $p=0.254$; left elbow; $p=0.353$ ), while statistically significant differences were found for extension and total ROM (right elbow extension, $\mathrm{p}<0.001$; left elbow extension, $\mathrm{p}<0.001$; right $\mathrm{ROM}, \mathrm{p}=0.002$; left elbow ROM, $\mathrm{p}=0.011$ ) (Table 4).

\section{DISCUSSION}

One of the main reasons for obesity in children is having no adequate opportunities to use their energy. This situation is related to a sedentary lifestyle ${ }^{[14]}$ and also difficulties based on child's
Table 3. Statistical analysis of right joint angle measurements to percentile

\begin{tabular}{lc}
\hline & $p^{*}$ \\
\hline Elbow extension** & 0.039 \\
Elbow flexion"** & 0.354 \\
Shoulder abduction** & 0.652 \\
Carrying angle** & 0.455 \\
Range of motion"** & 0.02 \\
\hline${ }^{*}$ Chi-square test; ${ }^{* *}$ Percentile. &
\end{tabular}

physical state. Since obese children are liable to dyspnea and also may have poor joint motion, they become inactive. ${ }^{[15]}$

The negative effects of obesity on the musculoskeletal system increases health risks, while simultaneously reducing patient's quality of life. Weight loss can facilitate the healing of musculoskeletal system disorders and improve the altered parameters. ${ }^{[16]}$

Obese people sweat much more than people who are of normal weight, while providing postural balance. ${ }^{[17]}$ Also, attempting to correct posture can inhibit motion requirement as well. Despite the undefined etiology, the knee flexion of obese children tend to have a weaker proprioception. ${ }^{[18]}$ Reduction of ROM negatively affects muscle flexibility and strength which accelerates and encourages a sedentary life. ${ }^{[19]}$

Although, there are many studies about obesity and its affect on lower extremity joints (because lower extremity joints carry the weight of the body), there are a very limited number of studies in the literature about the function of upper extremity joints in obese children.

Since the elbow joint is the most important joint for many sports, its contribution to obesity becomes more distinctive. Golden et al. ${ }^{[10]}$ measured 113 children's elbow ROM and carrying angle to evaluate the relationship between BMI and ROM. They established a negative correlation

Table 4. Comparing normal weight and obese groups angular

\begin{tabular}{lcccc}
\hline & Group 1 & & Group 3 & \\
\cline { 2 - 2 } & Mean \pm SD & & Mean \pm SD & $p^{*}$ \\
\hline Elbow extension & $173.23 \pm 6.35^{\circ}$ & & $175.48 \pm 7.20^{\circ}$ & $<0.001$ \\
Elbow flexion & $127.85 \pm 28.86^{\circ}$ & & $111.6 \pm 36.01^{\circ}$ & 0.846 \\
Shoulder abduction & $168.79 \pm 10.34^{\circ}$ & & $164.78 \pm 13.62^{\circ}$ & 0.032 \\
Carrying angle & $12.12 \pm 5.96^{\circ}$ & & $10.00 \pm 4.68^{\circ}$ & 0.04 \\
Range of motion & $121.10 \pm 28.66^{\circ}$ & & $107.09 \pm 36.22^{\circ}$ & $<0.001$ \\
\hline SD: Standard deviation; * Chi-square test. & & &
\end{tabular}


between BMI with elbow flexion and ROM, a positive correlation between BMI with right elbow extension, there was no correlation between left elbow extension or left and right carrying angles with BMI. ${ }^{[10]}$ Also in our study, a significant negative correlation was found between BMI with right and left $\mathrm{ROM}$ angle.

In the present study, we have also evaluated shoulder joint abduction angle and no correlation was found between BMI and shoulder abduction. In addition to the findings of Golden et al., ${ }^{[10]}$ we determined that the decrease of ROM was correlated with the restriction of extension movement.

There are several limitations with our study. Firstly, the age interval is proportionally wide. Secondly, measurements -variable ratios by age groups require cooperation from children, thus we may have been unable to ensure standardization. We evaluated only upper extremity joints, however lower extremity joints are much more effective in games and sportive activities. Therefore, the power of our comments could have been diminished.

In conclusion, obesity in childhood reduces the joint functions of upper extremities and leads to stiffness in joints, unwillingness to participate in sports (more sedentary situation) and progressive obesity. We believe that the motivation for obese child to take part in team sports or other sports which use the whole body, such as swimming, will improve extremity functions, whilst allowing the patient to expend many more calories.

\section{Declaration of conflicting interests}

The authors declared no conflicts of interest with respect to the authorship and/or publication of this article.

\section{Funding}

The authors received no financial support for the research and/or authorship of this article.

\section{REFERENCES}

1. Ogden CL, Carroll MD, Kit BK, Flegal KM. Prevalence of childhood and adult obesity in the United States, 2011-2012. JAMA 2014;311:806-14.

2. National Center for Health Statistics. Health, United States, 2011: With Special Features on Socioeconomic Status and Health. Hyattsville, MD; U.S. Department of Health and Human Services; 2012.
3. Freedman DS, Khan LK, Serdula MK, Dietz WH, Srinivasan SR, Berenson GS. The relation of childhood BMI to adult adiposity: the Bogalusa Heart Study. Pediatrics 2005;115:22-7.

4. Growth Reference Study Group. Geneva: World Health Organization; 2006. WHO child growth standards: Length/height-for-age, weight-for-age, weight-for length, weight-for-height and body mass index-for-age: Methods and development.

5. Li C, Ford ES, Zhao G, Mokdad AH. Prevalence of pre-diabetes and its association with clustering of cardiometabolic risk factors and hyperinsulinemia among U.S. adolescents: National Health and Nutrition Examination Survey 2005-2006. Diabetes Care 2009;32:342-7.

6. CDC. National diabetes fact sheet: national estimates and general information on diabetes and prediabetes in the United States, 2011 Adobe PDF file [pdf 2.7M]. Atlanta, GA: U.S. Department of Health and Human Services.

7. Daniels SR, Arnett DK, Eckel RH, Gidding SS, Hayman LL, Kumanyika S, et al. Overweight in children and adolescents: pathophysiology, consequences, prevention, and treatment. Circulation 2005;111:1999-2012.

8. Office of the Surgeon General. The Surgeon General's Vision for a Healthy and Fit Nation.. Rockville, MD, U.S. Department of Health and Human Services; 2010.

9. Dietz WH. Overweight in childhood and adolescence. N Engl J Med 2004;350:855-7.

10. Golden DW, Wojcicki JM, Jhee JT, Gilpin SL, Sawyer JR, Heyman MB. Body mass index and elbow range of motion in a healthy pediatric population: a possible mechanism of overweight in children. J Pediatr Gastroenterol Nutr 2008;46:196201.

11. U.S. Department of Health and Human Services. U.S. Department of Agriculture. Dietary Guidelines for Americans, 2005. 6th ed. Washington, D.C.: U.S. Government Printing Office, January 2005.

12. Gates DH, Walters LS, Cowley J, Wilken JM, Resnik L. Range of Motion Requirements for UpperLimb Activities of Daily Living. Am J Occup Ther 2016;70:7001350010p1-7001350010p10.

13. London JT. Kinematics of the elbow.J Bone Joint Surg [Am] 1981;63:529-35.

14. Sahoo K, Sahoo B, Choudhury AK, Sofi NY, Kumar R, Bhadoria AS. Childhood obesity: causes and consequences. J Family Med Prim Care 2015;4:187-92.

15. Niehoff V. Childhood obesity: A call to action. Bariatric Nursing and Surgical Patient. Care 2009;4:17-23.

16. Anandacoomarasamy A, Caterson I, Sambrook $\mathrm{P}$, Fransen M, March L. The impact of obesity on the musculoskeletal system. Int $\mathrm{J}$ Obes (Lond) 2008;32:211-22.

17. Greve J, Alonso A, Bordini AC, Camanho GL. 
Correlation between body mass index and postural balance. Clinics (Sao Paulo) 2007;62:717-20.

18. Wang L, Li JX, Xu DQ, Hong YL. Proprioception of ankle and knee joints in obese boys and nonobese boys. Med Sci Monit 2008;14:129-35.

19. O'Malley G, Hussey J, Roche E. A pilot study to profile the lower limb musculoskeletal health in children with obesity. Pediatr Phys Ther 2012;24:292-8. 